\title{
Fire increases the reproduction of the dominant grass Brachypodium retusum and Mediterranean steppe diversity in a combined burning and grazing experiment
}

\author{
Christel Vidaller | Thierry Dutoit | Hervé Ramone | Armin Bischoff
}

CNRS, IRD, Institut Méditerranéen de Biodiversité et d'Ecologie marine et continentale (IMBE), Univ Avignon, Aix Marseille Univ, Avignon Cedex 09, France

\section{Correspondence}

Christel Vidaller, CNRS, IRD, Institut Méditerranéen de Biodiversité et d'Ecologie marine et continentale (IMBE), Univ Avignon, Aix Marseille Univ, Avignon Cedex 09, France.

Email: christel.vidaller@gmail.com

Funding information

French Federal State PACA (PhD grant);

University of Avignon

\begin{abstract}
Aims: We assessed what the effects of fire and grazing are on vegetative growth and sexual reproduction of Brachypodium retusum, the dominant species of Mediterranean Thero-Brachypodietea grasslands ("steppes") and on species composition of the associated plant community.

Location: "La Crau", southeastern France.

Methods: We set up a split-plot experiment testing the effects of fire season (winter, summer) and grazing on plant cover, inflorescence number, seed set and germination of Brachypodium retusum in traditionally grazed grasslands. We further analyzed plant species composition and diversity in vegetation relevés. The same fire treatments were tested in a second experiment in long-term grazing exclosures.

Results: Brachypodium retusum showed a rapid post-fire recovery, but other species of the associated plant community, in particular annuals, recovered as fast or even faster. Fire increased Brachypodium retusum inflorescence production and seed set per inflorescence and this effect was stronger in the summer fire treatment. At the community level, fire significantly increased species richness, evenness and BrayCurtis dissimilarity in the second post-fire season and again, the summer fire effect was stronger. Grazing exclusion for two seasons had only a small effect on Brachypodium retusum and the associated plant community. The effect of both fire treatments on Brachypodium retusum was similar in long-term exclosures. In these exclosures, fire resulted in a community shift towards the species composition of traditionally grazed steppes.

Conclusions: The concomitant positive effects of experimental burning on Brachypodium retusum reproduction and on plant diversity of Mediterranean steppe vegetation suggest that the system is adapted to fire as an important driver of community composition. Annual species surviving as seeds are as successful in post-fire recovery as perennial resprouters. Prescribed burning may be an alternative strategy to restore community structure in abandoned (ungrazed) steppes showing a decline in typical grassland species after several years of grazing abandonment.
\end{abstract}

\section{KEYWORDS}

exclosures, Mediterranean grassland, plant community, plant-environment interactions, population dynamics, prescribed burning, Thero-Brachypodietea 


\section{1 | INTRODUCTION}

Mediterranean dry grasslands are semi-natural habitats that depend on human land use such as grazing and related fire management to maintain plant populations and communities (Bond \& Van Wilgen, 1996; Naveh, 1975). Both increased land use intensity, in particular transformation to arable use, and land abandonment followed by shrub encroachment are threatening these highly diverse ecosystems (San Miguel, 2008). As in other European grassland ecosystems, diversity is linked to traditional extensive land use (Gazol et al., 2012; Poschlod \& WallisDeVries, 2002; Pywell et al., 2007). Sheep grazing is a key land use factor driving plant species composition and diversity across a variety of grassland types (reviewed by Cingolani, Noy-Meir, \& Díaz, 2005). Wildfires and fire management by shepherds in the Mediterranean region were also important drivers until the industrial revolution, but their role in maintaining the ecosystem is nowadays less clear because fire suppression and abandonment of traditional pastoral fires have largely reduced their impact in the last decades (Naveh, 1975; Parr \& Andersen, 2006).

Many plant species and communities are adapted to fire and depend on specific fire regimes (Bond \& Van Wilgen, 1996). Changes in such disturbance regimes often lead to shifts in plant community composition (Bond \& Keeley, 2005). In Mediterranean "Matorral" (shrublands), an increase in fire frequency favors seeder shrubs such as Rosmarinus officinalis and resprouter grasses such as Brachypodium retusum (Vilà-Cabrera, Saura-Mas, \& Lloret, 2008). Accordingly, fire suppression may change community structure and diversity of such ecosystems (Bond, Woodward, \& Midgley, 2005). At the species level, plants with different adaptive strategies to survive fires have been selected over centuries (Buhk, Meyn, \& Jentsch, 2007). Resprouting from protected tissues and/or from undamaged below-ground organs are common strategies along with increased seed production, fire-resistant seeds, fire-stimulated germination or flowering (Clarke et al., 2013; Lamont \& He, 2017; Pyke, 2017). For example, some fynbos and chaparral geophyte species only start flowering after fire and disperse seeds on bare soil to benefit from reduced competition and higher nutrient availability (Keeley, 1993; Tyler \& Borchert, 2003).

Similarly to fire, grazing favors resprouting either from belowground organs or from the stem base (Briske \& Noy-Meir, 1998). This may be combined with other avoidance strategies such as small growth, early germination and flowering, and a short flowering period (Díaz, Noy-Meir, \& Cabido, 2001; Landsberg, Lavorel, \& Stol, 1999). In grasslands, seedling recruitment is often quite low because grazing and dense grassland swards may hamper seed production, germination and seedling recruitment (Drobnik, Römermann, Bernhardt-Römermann, \& Poschlod, 2011). However, Mediterranean steppe vegetation is a quite open grassland type and the grazing period is short, allowing the survival of many annual species (Briske \& Noy-Meir, 1998). Similar to fire, grazing increases mineralization of organic matter and nutrient availability during the seedling recruitment period (Bond \& Keeley, 2005). Although several studies have shown that grazing is needed to maintain the unique species composition of Mediterranean steppe communities (Briske \& Noy-Meir, 1998; Buisson \& Dutoit, 2006; San Miguel, 2008), the consequences of short-term and long-term grazing abandonment are not precisely known (Saatkamp, Henry, \& Dutoit, 2018). There is also a lack of studies analyzing the interaction of fire and grazing in Mediterranean grasslands. Annual fire may increase the productivity of ungrazed sites but not of recently grazed sites (Buis et al., 2009). The fire-by-grazing interaction was also found to depend on the annuals-perennials ratio of plant communities since annual species are usually less competitive in grazed habitats but may be favored by fire (Noy-Meir, 1995).

In our study, we analyzed fire and grazing effects in a Mediterranean steppe (Thero-Brachypodietea, San Miguel, 2008) dominated by the resprouter grass Brachypodium retusum. This steppe community is under decline and protected by the EU habitats directive (San Miguel, 2008). Brachypodium retusum is still widespread in the Mediterranean region but also suffers from the loss of this habitat. In ecological restoration, Brachypodium retusum shows poor re-establishment (Coiffait-Gombault, Buisson, \& Dutoit, 2012; Vidaller, Dutoit, Ibrahim, Hanslin, \& Bischoff, 2018) and it is obvious that restoration remains incomplete if the dominant species of pristine steppes is lacking. Thus, a better knowledge on the ecology of the species and on the effects of major management factors is needed to better conserve these plant communities. Fire and grazing are two key environmental/management factors that have largely decreased (fire protection, land abandonment) potentially explaining the decline of Mediterranean steppes (San Miguel, 2008).

Previous studies have demonstrated that Brachypodium retusum benefits from fire (Cassagne et al., 2011; Caturla, Raventós, Guàrdia, \& Vallejo, 2000; De Luis, Raventós, Cortina, González-Hidalgo, \& Sánchez, 2004). Although wildfires most frequently occur in undergrazed or abandoned areas, prescribed burning has also been frequently applied to improve forage quality in traditionally grazed areas (San Miguel, 2008; Stouff, 1986). The dense below-ground rhizome network of Brachypodium retusum allows a fast post-fire regrowth (Caturla et al., 2000; De Luis et al., 2004). Fire may increase reproductive stalk number (Caturla et al., 2000) but it is unknown whether fire also promotes seed set and viability. We further do not know whether fire season influences population and community dynamics of Mediterranean steppes and their dominant species. Wildfires mainly occur during the dry and hot summer period whereas shepherds burned grasslands at the end of winter (pastoral fires) to remove standing litter and favor resprouting (Stouff, 1986). Both fire types may also promote annual species by providing favorable conditions for autumn and spring germination.

Similarly, grazing was found to have a positive effect on the growth of Brachypodium retusum (Coiffait-Gombault et al., 2012) and on the diversity of its associated plant community (Saatkamp et al., 2018). However, grazing may reduce sexual reproduction due to vegetative biomass and/or inflorescence removal (Vidaller et al., 2018). We were particularly interested in combined grazing and fire effects on the dominant species Brachypodium retusum and on 
its associated plant community. We hypothesize that both fire and grazing favor Brachypodium retusum relative to other species of the plant community. We further hypothesize that both perennial resprouters and annual species benefit from fire and grazing, thereby increasing biodiversity and changing plant species composition. Our last hypothesis is that fire effects are stronger in ungrazed situations and that prescribed burning may be an efficient strategy to restore steppe communities in undergrazed or abandoned grasslands. We set up two experiments to specifically address the following research questions:

1. What are the effects of fire and grazing on the vegetative growth and sexual reproduction of Brachypodium retusum compared with co-occurring species cover of the Mediterranean steppe?

2. How do fire and grazing affect plant species composition and diversity?

3. Do fire effects depend on season and can fire help to maintain diversity of grazed or abandoned grasslands?

\section{2 | METHODS}

\section{1 | Study area}

The study was set up in the "Crau" Mediterranean grassland ("steppe", EUNIS habitat E1.311, Natura 2000 habitat type 6220; European Commission, 2007) in southeastern France. The study region is characterized by hot/dry summers and mild/humid winters with an annual precipitation of $517 \mathrm{~mm}$ (1980-2010) and a mean temperature of $15.3^{\circ} \mathrm{C}$ (Meteo-France, meteorological station of Saint-Martinde-Crau; Appendix S1). Summer drought is common but the summer of 2016 was even drier than average $(55 \mathrm{~mm}$ instead of $100 \mathrm{~mm}$ on average). The soils of the study area are decalcified Red Mediterranean Soils (haplic Cambisol) with a mean $\mathrm{pH}$ of 6.8 . The vegetation has been shaped by a long history of grazing back to the Neolithic (Henry, Talon, \& Dutoit, 2010) and by former winter fires (Chalvet, 2016; Stouff, 1986). The steppe is still annually grazed by itinerant sheep during spring. Due to risks for inhabitants and land users, winter fires have not been used as a management strategy since the end of the 19th century (Chalvet, 2016). However, wildfires still occur during summer, in particular close to roads and field tracks. No fire was observed at the study site since 1973 (Prométhée fire database, 2018).

The grassland is species-rich, dominated by annual plants and the perennial grass Brachypodium retusum (Buisson \& Dutoit, 2006; Appendix S2). In long-term grazing exclosures (since 2001), $40 \%$ of initially occurring grassland species disappeared and have been replaced by high-growing herbaceous ruderal species (Saatkamp et al., 2018).

The study species, Brachypodium retusum (Pers.) P. Beauv. (ramose false brome, Poaceae), is a perennial grass species. Its rhizomes form a dense network close to the soil surface allowing resprouting after destruction of above-ground organs by fire or grazing (Caturla et al., 2000). The species shows tillering at the stem base but also lateral branching at upper stem parts. Clonal growth is common but slow. Brachypodium retusum usually flowers from April to July but grazed or cut plants may also flower later in the season. At grazed sites, the species is highly dominant. Long-term grazing exclosure results in an increase of Brachypodium retusum height and the development of other competitive perennial grass species such as Dactylis glomerata (Saatkamp et al., 2018).

\section{2 | Design}

Two experiments testing the effect of late-winter fires (= winter fires) simulating pastoral fires, summer wildfires (= summer fires) and sheep grazing were set up in March 2016 and run for two seasons. The winter fire treatment was applied once in March 2016 and the summer fire treatment once in July 2016. In the first experiment, fire treatments were applied to the traditionally grazed steppe (Appendix S3, A). In the second experiment, fire treatments were applied to long-term grazing exclosures (abandoned grassland; Appendix S3, B).

\subsection{1 | Effect of fire and grazing in a traditionally managed steppe area (experiment 1 )}

The experiment was set up at two different sites comprising three

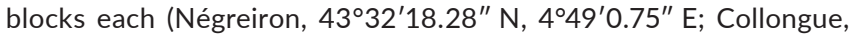
$\left.43^{\circ} 31^{\prime} 37.55^{\prime \prime} \mathrm{N}, 4^{\circ} 49^{\prime} 55.82^{\prime \prime} \mathrm{E}\right)$ to reflect heterogeneity in grazing but the site effect was finally pooled into block for statistical analysis in order to increase parsimony.

Blocks were split into two parts (half-blocks) of which one was fenced to prevent grazing. The three fire treatments (summer fire, winter fire, no fire) were applied to three plots of $4 \mathrm{~m}^{2}$ within each of the twelve half-blocks (split-plot design) in order to test combined effects of fire and grazing (36 plots in total). The distance between plots within half-blocks was $1 \mathrm{~m}$, between half-blocks within blocks $50 \mathrm{~m}$ and between blocks at least $200 \mathrm{~m}$. The position of fire treatments was randomized within half-blocks and that of grazing treatment was randomized within blocks.

A thermal weeder was used to burn plots to simulate winter fire and summer wildfire. Thermal weeding was achieved using a portable device with a gas cylinder and a ramp comprising four nozzles for flame weeding (Appendix S4). Due to fast fire spread during summer, we removed the device once the vegetation was burning. We stopped the fire manually when flames arrived at the plot border. To prevent grazing, the control half-blocks were fenced with stretched, non-electrified nets ( $1 \mathrm{~m}$ high). The other half-blocks allowed free sheep grazing during the grazing period from April to June. The mean grazing intensity was 646 sheep ha ${ }^{-1}$ season $^{-1}$ at the Négreiron site and 328 sheep ha ${ }^{-1}$ season $^{-1}$ at the Collongue site.

In July 2016, the above-ground vegetation was harvested in two plots of $50 \times 50 \mathrm{~cm}$ in each grazed and ungrazed half-block to measure biomass removal by sheep. Samples were dried at $80^{\circ} \mathrm{C}$ to a constant biomass and weighed afterwards. Grazing reduced 
above-ground biomass from $70 \pm 11 \mathrm{~g} / \mathrm{m}^{2}$ in ungrazed plots to $50 \pm 9 \mathrm{~g} / \mathrm{m}^{2}$ at the end of the grazing period.

\subsubsection{Effect of fire in long-term grazing exclosures (experiment 2)}

The same fire treatments were established in long-term grazing exclosures. The above-ground vegetation was harvested as described above. Standing biomass $\left(110 \mathrm{~g} / \mathrm{m}^{2} \pm 16\right)$ was twice as high as in traditionally grazed steppe areas. The design included three plots per block comprising the three fire treatments and six replicate blocks (18 plots in total). Corresponding to the first experiment, three blocks set up at the Négreiron site were fenced in August 2001 (3 ha) and three blocks at the Collongue site were fenced in June 1999 (2.9 ha). The distance between blocks and to exclosure fences was at least $50 \mathrm{~m}$.

\section{3 | Data collection}

\subsection{1 | Brachypodium retusum survey}

The cover percentage of the species was estimated at six dates (May, July, October 2016 and February, May, July 2017) including two growing seasons. At the same time, total vegetation cover was estimated. Cover was measured as the vertical projection of all above-ground organs. Visual cover estimation is as reliable as the more objective pin-point or point-intercept method and allows an analysis of larger areas (Damgaard, 2014; Symstad, Wienk, \& Thorstenson, 2008). Cover values were always estimated within one day by the same person to avoid observer bias. Brachypodium retusum cover was divided by total vegetation cover to obtain weighted cover. The cover of May 2016 and 2017 was finally used for analyses representing peak above-ground biomass in unburned plots before above-ground organs partially die due to summer drought. The regeneration of Brachypodium retusum was measured by comparing the May 2017 and October 2016 cover. In order to evaluate sexual reproduction, the number of inflorescences was counted in each plot during the flowering peak in July 2016 and 2017. At the same time, twenty inflorescences per plot were harvested to count seeds. If the number of inflorescences per plot was lower than twenty all inflorescences were sampled. Seeds were prepared by crushing the inflorescences in a plastic tube with glass beads using a vortex, then spreading the separated spikelets on an overhead projector in order to check whether spikelets are filled. Empty seeds or spikelets were removed from seed counts. Seeds were stored at room temperature and germinated in peat plugs $(4 \times 4 \mathrm{~cm})$. Four seeds of each experimental plot (block $\times$ treatment combination) were sown to one plug. The plug trays were placed in a growth chamber under optimum germination conditions (temperature $15 / 20^{\circ} \mathrm{C}, 12 / 12 \mathrm{~h}$ night/day - Vidaller et al., 2018) and watered regularly. Coleoptile emergence was used as a proxy of germination and was recorded every 2-3 days for seven weeks.

\subsection{2 | Vegetation survey}

The species composition of the associated plant community was analyzed in May 2016 and May 2017 during the peak of flowering. The cover of all vascular plant species was estimated using a modified Braun-Blanquet scale (Braun-Blanquet, 1932: $+=1$ individual per plot, $1 \%-5 \%$ cover, 2: 5\%-25\%, 3: 26\%-50\%, 4: 51\%-75\%, 5: >75\%). Contrary to the Brachypodium retusum survey, the sum of individual species' cover may be higher than $100 \%$.

\subsection{Data analysis}

In the combined fire and grazing experiment, a split-plot ANOVA was performed to analyze fire treatment and grazing effects on individual response variables (individual species cover, Brachypodium retusum inflorescence, seed number and germination rate, species richness, diversity indices). Grazing (whole-plot factor) was tested against the block $\times$ grazing interaction. Fire (split-plot factor), the fire $\times$ grazing interaction and block were tested against the model residuals. In the long-term exclosure experiment, a reduced model was applied only including the fire treatment and block. When necessary $\log 10(x+1)$ and square-root transformations were used to comply with assumptions of linear models (normality, homoscedasticity). A Tukey HSD post-hoc test was calculated to analyze differences between treatment levels if treatment main effects or interactions were significant.

In order to analyze plant community data, Braun-Blanquet scores were transformed into percentage cover: $+=0.5 \% ; 1=2.5 \%$; $2=15.0 \% ; 3=37.5 \% ; 4=62.5 \% ; 5=87.5 \%$. Species richness $(S)$, evenness $\left(J^{\prime}\right)$ and Bray-Curtis index (BC) were calculated using the vegan v2.4-2 package ( $R$, version 3.3.1, $R$ Development Core Team 2013). $J^{\prime}$ evenness was calculated as $H^{\prime} / \ln (S)$, with $H^{\prime}$ being the Shannon diversity index (Pielou, 1969). Species composition was compared using NMDS (Non-Metric Multidimensional Scaling, metaMDS function) based on the similarity index of Bray-Curtis (Borcard, Gillet, \& Legendre, 2011) in order illustrate changes in plant species composition as well as the species most correlated with each treatment. NMDS analyses were run using 30 random starting configurations in 1-15 dimensions. The run with the lowest stress value was finally applied. A permutation multivariate analysis of variance (PERMANOVA, Anderson, 2001) with 9,999 permutations was used to test whether the community composition was significantly different between the fire and grazing treatments. A pairwise post-hoc test with Bonferroni adjustment was calculated to analyze differences between levels of the fire treatment. All statistical analyses were run in $\mathrm{R}$ including multivariate analyses using the vegan package.

\section{3 | RESULTS}

\section{1 | Brachypodium retusum survey}

In the combined fire and grazing experiment, fire significantly reduced Brachypodium retusum cover in the following two years (Table 1; Appendix S5). Several months after fire treatments 
TAB LE 1 ANOVA F-values and significance level for effects of fire and grazing on Brachypodium retusum in the two experiments: cover and weighted cover adjusted for total vegetation cover (both May), post-fire regeneration (cover difference between October 2016 and May 2017), inflorescence number, seed number per inflorescence (both July) and germination rate

\begin{tabular}{|c|c|c|c|c|c|c|c|c|}
\hline & & $d f$ & Cover (\%) & $\begin{array}{l}\text { Weighted } \\
\text { cover (\%) }\end{array}$ & Regeneration (\%) & $\begin{array}{l}\text { Inflorescences } \\
\text { (number } / 4 \mathrm{~m}^{2} \text { ) }\end{array}$ & Seeds (number/inflor) & Germination (\%) \\
\hline \multicolumn{9}{|c|}{ (A) Combined fire and grazing experiment } \\
\hline \multirow[t]{3}{*}{2016} & Fire & 1.10 & $469.29^{* * *} \downarrow$ & $365.43^{* * *} \downarrow$ & & $18.99^{* * *} \downarrow$ & $42.44^{* * *} \downarrow$ & $4.06 * \uparrow$ \\
\hline & Grazing & 1.10 & $0.39 \mathrm{NS}$ & $1.43 \mathrm{NS}$ & & $0.18 \mathrm{NS}$ & $0.56 \mathrm{NS}$ & $0.01 \mathrm{NS}$ \\
\hline & $F \times G$ & 1.10 & $0.13 \mathrm{NS}$ & $0.13 \mathrm{NS}$ & & 0.09 NS & $1.59 \mathrm{NS}$ & $0.03 \mathrm{NS}$ \\
\hline \multirow[t]{3}{*}{2017} & Fire & 2.20 & $12.35^{* * *} \downarrow$ & $2.21 \mathrm{NS}$ & $143.04^{* * *} \uparrow$ & $11.48^{* * *} \uparrow$ & $5.86^{* *} \uparrow$ & $1.25 \mathrm{NS}$ \\
\hline & Grazing & 1.10 & $1.62 \mathrm{NS}$ & $0.58 \mathrm{NS}$ & $1.12 \mathrm{NS}$ & $0.01 \mathrm{NS}$ & $0.24 \mathrm{NS}$ & $0.35 \mathrm{NS}$ \\
\hline & $F \times G$ & 2.20 & $3.64^{*}$ & $3.62 *$ & $0.65 \mathrm{NS}$ & $0.90 \mathrm{NS}$ & $0.18 \mathrm{NS}$ & $0.31 \mathrm{~S}$ \\
\hline \multicolumn{9}{|c|}{ (B) Fire experiment in long-term exclosures } \\
\hline 2016 & Fire & 1.10 & $311.00^{* * *} \downarrow$ & $115.60^{* * *} \downarrow$ & & $1.10 \mathrm{NS}$ & $1.08 \mathrm{NS}$ & $0.87 \mathrm{NS}$ \\
\hline 2017 & Fire & 2.20 & $0.66 \mathrm{NS}$ & $1.85 \mathrm{NS}$ & $72.94^{* * *} \uparrow$ & $3.76 . \uparrow$ & $2.27 \mathrm{NS}$ & - \\
\hline
\end{tabular}

Note. $\mathrm{F} \times \mathrm{G}=$ fire $\times$ grazing interaction. $. p<0.1 ;{ }^{*} p<0.05 ;{ }^{* *} p<0.01 ;{ }^{* * *} p<0.001$, NS not significant. Factor effect: $\downarrow$ :decrease; $\uparrow:$ increase.

(October 2016), even cover relative to neighboring plants (weighted cover) was lower (Table 1). Accordingly, inflorescence and seed production were significantly reduced but a higher germination rate was found in seeds produced in winter fire plots compared with control plots (Table 1). In the second post-fire year (2017), the fire's main effect on weighted cover of Brachypodium retusum was not significant any more (Figure 1a, Table 1). Brachypodium retusum showed a rapid regeneration of its vegetative cover in the burned plots (Figure 1c, Table 1) compared with control plots in which its cover decreased from 2016 to 2017. At the end of the survey period in July 2017, inflorescence number was higher in burned plots but differences were only significant
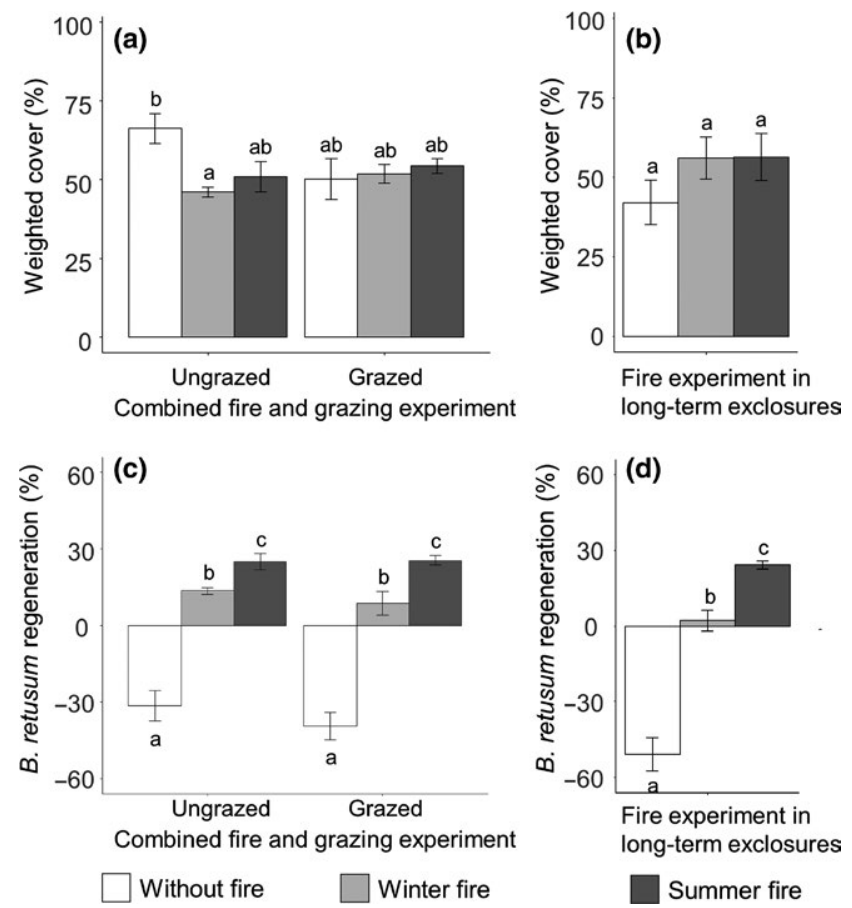

FIGURE 1 Effects of fire and grazing on vegetative growth of Brachypodium retusum in the combined fire and grazing experiment (left) and the fire experiment in long-term exclosures (right). (a,

b) Weighted cover one year after fire treatments (May 2017, mean $\pm \mathrm{SE}$ ); (c, d) Post-fire regeneration of cover (mean difference between October 2016 and May 2017, \pm SE) . Different lower case letters indicate significant differences $(P<0.05)$
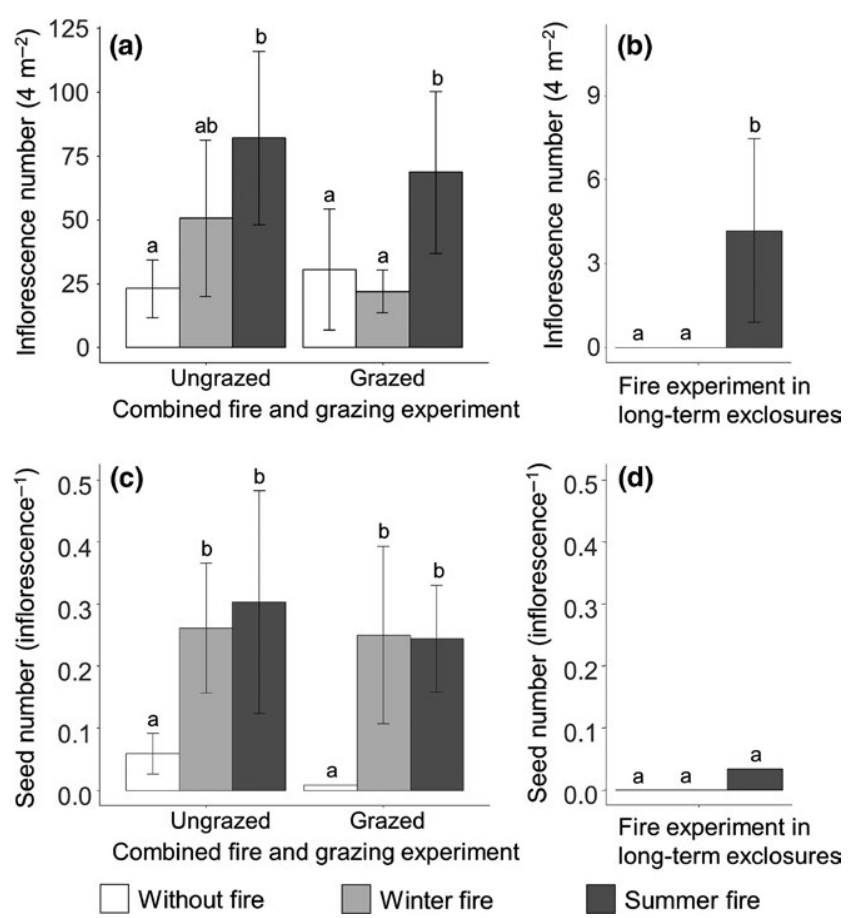

FIGURE 2 Effects of fire and grazing on the reproduction of Brachypodium retusum (mean $\pm \mathrm{SE}$ ) in the combined fire and grazing experiment (left) and the fire experiment in long-term exclosures (right) in the second post-fire year (July 2017). (a, b) Inflorescence number; (c, d) seed number per inflorescence. Different lower case letters indicate significant differences $(P<0.05)$ 
between summer fire treatment and control (Figure 2a, Table 1). We also found a significantly higher seed number per inflorescence in summer and winter fire plots (Figure 2c, Table 1) whereas germination rate was no longer different between seeds from the different treatments.

The effect of grazing was not significant for any of these variables (Table 1). Only a significant fire $\times$ grazing interaction occurred in 2017 for Brachypodium retusum cover. Grazing reduced absolute and weighted cover in unburned controls.

In the long-term exclosures, fire effects were similar to those in the combined grazing and fire experiment (Table 1). Cover (weighted and non-weighted), inflorescence number and seed number per inflorescence decreased in the beginning of the first year, but recovered rapidly in the second post-fire year (Table 1, Figure 1b, d). Although absolute Brachypodium retusum cover was still lower in 2017, relative (weighted) cover was no longer different to the control whereas inflorescence number was even higher in the summer fire treatment compared with the unburned control (marginally significant). Due to the low seed set in all treatments, differences in seed number per inflorescence were not significant.

\section{2 | Plant community}

In the combined fire and grazing experiment, fire significantly reduced species richness three months after treatments in 2016 but one year later, in 2017, species richness was significantly higher in burned plots than in unburned controls (Table 2, Figure 3 ). The second year, differences in species richness were significant between summer fire and control plots whereas winter fire species richness was not different from that in the other treatments. In both years, evenness and Bray-Curtis dissimilarity were significantly higher in the fire treatments. Regardless of the year, grazing effect and the fire $\times$ grazing interaction were not significant.

In the long-term exclosures, species richness was not significantly affected three months after fire treatment (May 2016) but in the second year, a significant increase was measured between
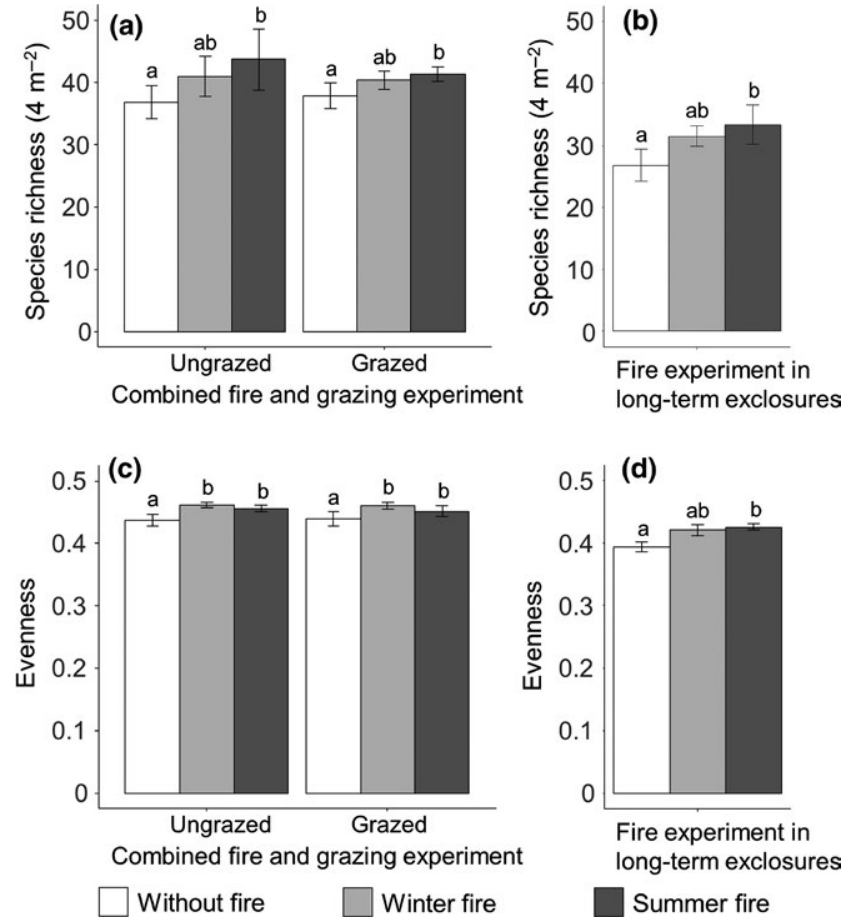

FIGURE 3 Effects of fire and grazing on the plant community (mean \pm SE) one year after fire treatments (May 2017) in the combined fire and grazing experiment (left) and the fire experiment in long-term exclosures (right). (a, b) Species richness; (c, d) evenness . Different lower case letters indicate significant differences $(P<0.05)$

summer fire and control. As in the first experiment, evenness (marginally) and Bray-Curtis dissimilarity were significantly higher in burned plots compared to values in the controls. However, the fire effect on Bray-Curtis dissimilarity was no longer significant in the second post-fire year.

In 2017, one year after fire treatments, NMDS ordination showed a clear separation between the plant community of the combined fire and grazing experiment in the steppe area and the fire

\begin{tabular}{|c|c|c|c|c|c|}
\hline & & $d f$ & Species richness & Evenness & Bray-Curtis \\
\hline \multicolumn{6}{|c|}{ (A) Combined fire and grazing experiment } \\
\hline \multirow[t]{3}{*}{2016} & Fire & 1.10 & $4.97^{*} \downarrow$ & $12.26^{* *} \uparrow$ & $24.14^{* * *} \uparrow$ \\
\hline & Grazing & 1.10 & $0.45 \mathrm{NS}$ & $0.01 \mathrm{NS}$ & $0.45 \mathrm{NS}$ \\
\hline & $F \times G$ & 1.10 & $0.01 \mathrm{NS}$ & 3.12 NS & $0.16 \mathrm{NS}$ \\
\hline \multirow[t]{3}{*}{2017} & Fire & 2.20 & $4.18^{*} \uparrow$ & $14.00^{* * *} \uparrow$ & $3.32^{*} \uparrow$ \\
\hline & Grazing & 2.20 & 0.03 NS & $0.00 \mathrm{NS}$ & $0.04 \mathrm{NS}$ \\
\hline & $F \times G$ & 2.20 & $0.42 \mathrm{NS}$ & $0.31 \mathrm{NS}$ & $0.40 \mathrm{NS}$ \\
\hline \multicolumn{6}{|c|}{ (B) Fire experiment in long-term exclosures } \\
\hline 2016 & Fire & 1.10 & $3.05 \mathrm{NS}$ & $4.82 . \uparrow$ & $32.06^{* *} \uparrow$ \\
\hline 2017 & Fire & 2.10 & $5.03 * \uparrow$ & $3.95^{*} \uparrow$ & $1.45 \mathrm{NS}$ \\
\hline
\end{tabular}

TABLE 2 ANOVA $F$-values, significance levels for effects of fire and grazing on species richness (per $4 \mathrm{~m}^{2}$ ), evenness and Bray-Curtis dissimilarity in the two experiments

Note. $\mathrm{F} \times \mathrm{G}=$ fire $\times$ grazing interaction. $. p<0.1{ }^{*} p<0.05 ;{ }^{* *} p<0.01 ;{ }^{* * *} p<0.001$, NS not significant. Factor effect: $\downarrow$ : decrease; $\uparrow$ : increase. 
FIGURE 4 Effect of fire on plant species composition in the combined fire and grazing experiment set up in traditionally managed steppe and in the fire experiment set up in long-term exclosures using NMDS on May 2017 data. Polygons indicate the position of the outmost plots in each treatment (NMDS stress: 0.147 , nine dimensions)

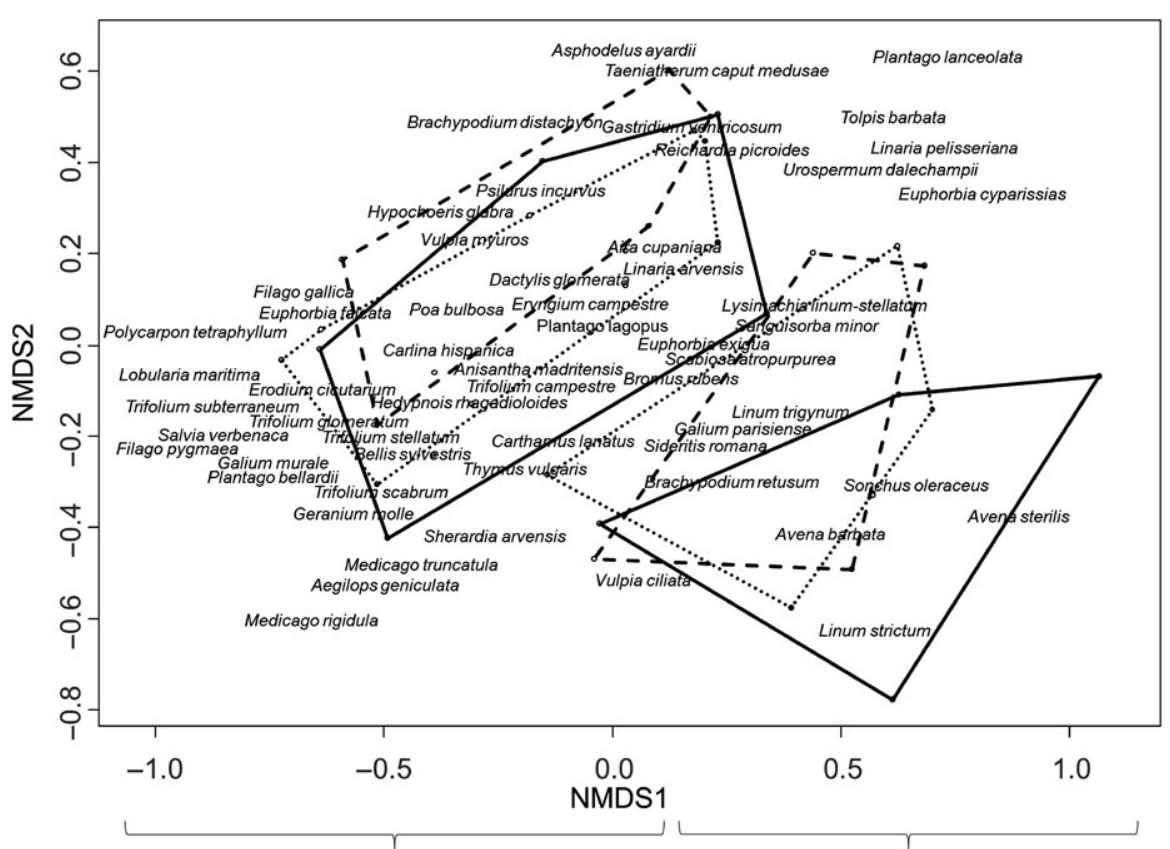

Combined fire and grazing experiment Fire experiment in long-term exclosures experiment in long-term exclosures (Figure 4). Along axis 1 of the NMDS, Brachypodium retusum and ruderal species such as Sonchus oleraceus, Avena sterilis and Avena barbata characterize the vegetation of the long-term exclosures, whereas short annual and stress-tolerant species such as Polycarpon tetraphyllum, Filago pygmaea, Euphorbia falcata, Galium murale are more abundant in the traditionally managed steppe. In the long-term exclosures, fire changed the plant community more than in the steppe (Figure 4). The burned long-term exclosures were closer to the traditionally managed steppe than the unburned controls. The PERMANOVA testing differences in species composition between treatments showed a significant effect of fire in the combined fire and grazing experiment $\left(F_{2,35}=2.865^{*}\right)$ and in long-term exclosures (marginally significant, $F_{2,17}=1.78^{(*)}$ ). In the combined fire and grazing experiment, the effect of summer fire was stronger than that of winter fire whereas no such differences occurred in the long-term exclosures (Appendix S6). The effect of grazing and the grazing $\times$ fire interaction was not significant (grazing: $F_{135}=1.512^{\mathrm{NS}}$, fire $\times$ grazing: $F_{2,35}=0.212^{\mathrm{NS}}$ ).

In both experiments, the cover of annual species such as Medicago monspeliaca, Euphorbia falcata, and Bromus rubens as well as the perennial grass Poa bulbosa particularly benefitted from fire treatments (Appendix S7). In particular, summer fire had a strong positive effect on the cover of Medicago monspeliaca and Brachypodium rubens whereas Euphorbia falcata and Poa bulbosa also benefitted from winter fire. The grazing effect was not significant for these species.

\section{DISCUSSION}

Across the tested populations of the dominant plant species Brachypodium retusum and the associated plant community, the fire effect was much stronger than the grazing effect. Grazing reduced above-ground biomass by $40 \%$ but did not significantly influence the majority of measured Brachypodium retusum traits and community parameters. Fire had a similar effect in the combined fire and grazing experiment at traditionally managed sites and in the long-term exclosures, allowing a fast recovery of typical steppe species such as Brachypodium retusum.

\subsection{Effects of fire and grazing on Brachypodium retusum}

Brachypodium retusum can survive fire by resprouting from rhizomes favored by axillary buds (Clarke et al., 2013). Adapted plant species such as rhizomatous resprouters may even benefit, since fire increases resource availability (Neary, Klopatek, DeBano, \& Ffolliott, 1999), stimulates re-growth from below-ground buds (Fidelis, Appezzato-daGlória, Pillar, \& Pfadenhauer, 2014) and opens the canopy, reducing competition for light, water and nutrients (Everson \& Everson, 1987). In our study, Brachypodium retusum cover increased rapidly after fire whereas controls showed a decrease in cover due to the summer drought in 2016. In particular, reduced competition for water resulting from biomass removal was likely the reason for the better post-fire regeneration (Everson \& Everson, 1987). However, in the first season weighted cover of Brachypodium retusum relative to total vegetation cover was significantly lower in fire treatments than in the control, indicating that its post-fire regeneration was slower than that in other species of the plant community. Thus, our results do not confirm studies in eastern Spain showing a faster recovery of Brachypodium retusum compared to accompanying species and resulting in a rapid increase of weighted Brachypodium retusum cover (Caturla et al., 2000; De Luis et al., 2004). 
Regeneration was faster in the summer than in the winter fire treatment, suggesting that Brachypodium retusum is better adapted to natural summer fire. The period of fire management by shepherds may not have been long enough for an evolutionary response, whereas summer fire disturbance is much older, allowing adaptive processes. The stronger summer fire effect on Brachypodium retusum regeneration may also be the result of a higher standing biomass and a lower water content (dry leaves and stems) corresponding to higher fire temperatures and biomass loss compared with winter fire (Hobbs, Schimel, Owensby, \& Ojima, 1991; Trabaud, 1979). Nevertheless, it is already well known that the traditional winter fire management improves pasture quality and vigor by allowing the regeneration of above-ground biomass in Brachypodium retusum (Stouff, 1986).

In the long-term exclosures, fire effects on Brachypodium retusum cover were similar to those of the combined grazing and fire experiment in the traditionally managed steppe. However, the species reached cover values of the unburned control already in the second post-fire year, indicating a faster recovery. Long-term exclosure from grazing results in a strong biomass increase mainly due to the growth of perennial grass species (Bond \& Parr, 2010). Abandonment of grazing also increases litter biomass and $\mathrm{C}: \mathrm{N}$ ratios, and decreases soil nutrient content (Peco, Carmona, de Pablos, \& Azcárate, 2012; Saatkamp et al., 2018). Thus, fire temperatures are higher and therefore fire has a stronger effect on plant species than in grazed systems with lower living and dead biomass (Hobbs, Schimel, Owensby, \& Ojima, 1991). The high recovery of Brachypodium retusum in our exclosures suggests that wildfire or prescribed burning may help to maintain the typical species composition and community structure in long-term absence of grazing.

In addition to vegetative resprouting, fire increased the allocation of resources to reproductive organs in the second post-fire year, favoring seed production and quality. The production of inflorescences was significantly higher in both fire treatments, but in particular after summer fire. Fire-stimulated flowering is already known for several species in the Mediterranean regions of Australasia and South Africa, with peak flowering occurring five to eighteen months after fire (Lamont \& Downes, 2011; Pyke, 2017). Flowering may be triggered by fire-specific cues such as chemical compounds of smoke and ash or scorching of below-ground storage organs (Keeley, 1993; Tyler \& Borchert, 2003) but also by a fire-induced increase in light and temperature (Fidelis \& Blanco, 2014). As with resprouting, inflorescence production may be favored by a higher resource availability due to reduced competition and higher nutrient or water availability (Coates, Lunt, \& Tremblay, 2006).

Fire also increased the seed set measured as seed production per inflorescence in the second post-fire year whereas high fire damage to photosynthetically active tissues (leaves, stems) reduced seed set in the first year. A higher post-fire seed set in the following years was also measured for two Australian perennials (Lamont \& Runciman, 1993). The effect on ex-situ germination was less strong, being positive only in the same year as the fire treatments. In the second season, when the increase in inflorescence production and seed set occurred, differences in germination were not significant any more. Germination is an important trait under selection for adaptation to fire (Keeley, Bond, Bradstock, Pausas, \& Rundel, 2012). Many species from a wide range of taxa show a rapid and increased germination after fire (González-Rabanal, Casal, \& Trabaud, 1994; Naveh, 1975). However, Brachypodium retusum seeds were produced after fire, excluding a direct exposure to fire cues. Our germination experiment was set up in a growth chamber, not taking into account modified conditions in burned plots (nutrient availability, destruction of organic matter, presence of ashes, etc.). Moreover, in some species of fire-prone ecosystems, there is no evidence that fire triggers germination (Le Stradic et al., 2015).

Grazing's main effect on vegetative growth and on reproduction was neither significant in the first nor in the second season. Although the statistical power to test grazing as the whole-plot factor of the split-plot design was lower than for fire as split-plot factor, the small differences between grazing treatment means confirm that the impact of grazing is much less strong than that of fire. Brachypodium retusum tolerates the short-term absence of grazing even though grazing is an important factor in maintaining population cover (Coiffait-Gombault et al., 2012). However, a significant fire $\times$ grazing interaction was measured during the second season with plant cover being lower only in unburned plots. The result confirmed our hypothesis that fire impact is stronger in ungrazed situations. Higher fire temperatures due to higher litter biomass, already cited for abandoned grasslands (Peco et al., 2012, Hobbs et al., 1991), may have increased the impact of fire in ungrazed control plots. However, this significant interaction was also visible in winter fire plots that were burned before grazing. This effect could be explained by the behavior of sheep avoiding recently burned Brachypodium retusum plants, thus increasing the positive effect of fire by reducing postfire biomass consumption.

\subsection{Effects of fire and grazing on the plant community}

In the combined fire and grazing experiment, fire reduced species richness three months after treatments but in the second year, the fire effect was already strongly positive. Fire also increased evenness by removing biomass of the dominant Brachypodium retusum and the community dissimilarity. Infrequent and/or irregular fire disturbance may result in species loss and community composition changes (Laurance, 2003). However, in fire-prone ecosystems, such disturbance maintains species richness and community structure (Bond et al., 2005; Fidelis, Blanco, Müller, Pillar, \& Pfadenhauer, 2012). Accordingly, fire suppression may considerably reduce plant diversity of fire-prone systems (Leach \& Givnish, 1996; Sparks, Masters, Engle, Palmer, \& Bukenhofer, 1998).

Again, the effect of summer fire was stronger than that of winter fire. Fire season was found to affect plant communities. Fire during the growing season may, for example, increase plant diversity, in particular the number of annuals and cool-season perennials, whereas no such effect was observed for dormant-season (fall, spring) fire (Biondini, Steuter, \& Grygiel, 1989; Howe, 1994). The growing season 
of Brachypodium retusum and most other species of the community starts in late winter and lasts until July, corresponding to the two fire dates. The stronger summer fire effect may be the result of a higher standing biomass and a lower water content (dry leaves and stems) corresponding to higher fire temperatures and biomass loss (Hobbs et al., 1991; Trabaud, 1979).

The fire effect on long-term exclosures was similar to that on traditionally managed steppe plots. Fire generally increased diversity in the second season. Contrary to the traditionally managed steppe, there was no decrease in species richness, confirming the particularly beneficial effect of fire in abandoned grassland for conserving species-rich dry grasslands (Bond \& Parr, 2010). The plant species composition of burned long-term exclosures was closer to the traditionally managed steppe than that of the unburned control.

In both experiments and systems, differences in species composition were mainly explained by an increase in native annual seeder species, whereas fire reduced the cover of resprouter grasses in the first post-fire year. Similar to the results on the dominant species Brachypodium retusum, fire-induced community changes do not correspond to those of earlier studies in Spanish Brachypodium retusum grasslands (Caturla et al., 2000; De Luis et al., 2004). The La Crau steppe is a more open and less nutrient-rich grassland type than the Spanish field sites, allowing the development of a higher diversity of annual species (Buisson \& Dutoit, 2006). Apart from resprouting, seedling recruitment is therefore a second successful strategy of postfire regeneration, as is already known for other dry and nutrient-poor grasslands (Valone \& Kelt, 1999). Although the short study period does not allow conclusions on the duration of facilitative effects, we were able to demonstrate that fire helps annual species to develop. Further research is needed to identify the optimum frequency of fire disturbance to maintain such positive effects on plant diversity.

Grazing was expected to have positive but less strong effects on plant diversity of the steppe community. Such positive effects are mediated by sward opening, biomass reduction and soil surface disturbance (Coiffait-Gombault et al., 2012; Saatkamp et al., 2018). In our study, the effects of grazing and the interaction between fire and grazing were not significant. Again, the small differences between treatment means confirmed that grazing has a much smaller effect than fire in spite of the lower statistical power for testing whole-plot effects. The hypothesis that fire effects are stronger in ungrazed situations was not supported at the community level. As already demonstrated for the dominant species Brachypodium retusum, the plant community tolerated the short-term absence of grazing without species loss or differences in diversity indices. These findings confirmed results of a previous study in the same system showing only small changes in the first five years after grazing abandonment (Saatkamp et al., 2018).

\section{5 | CONCLUSIONS}

We showed a concomitant positive effect of fire on the reproduction of the dominant grass Brachypodium retusum and the species diversity of its associated plant community. Contrary to our expectations, fire did not favor perennial resprouters such as Brachypodium retusum over annuals, confirming that both strategies, resprouting from below-ground organs and seedling recruitment, are successful in short term post-fire vegetation recovery. Short-term grazing exclusion had only small effects on Brachypodium retusum and the associated plant community. However, the long-term exclosures abandoned 17 years before our experiments showed large differences to the traditionally managed steppe such as a lower Brachypodium retusum reproduction and a lower plant diversity. In such abandoned or undergrazed systems, fire has a particularly positive effect on Brachypodium retusum performance and plant diversity and may thus compensate for long-term grazing absence to conserve this unique Mediterranean grassland ecosystem.

\section{ACKNOWLEDGEMENTS}

We thank Sébastien Dailly, Julien Formento, Hugo Lezarme, Cannelle Moinardeau, Julie Chenot, Jean-François Alignan, Olivier Blight, Daniel Pavon and Elise Buisson for field assistance. Perrine Lagarde and Aline Le Menn helped in running germination tests. We also thank Fanny Sauguet for identifying field plots and the sheep farmers Mr. Tavan and Ms Trouillard, the Federal State Nature Conservation Authority (CEN-PACA) and Crau Nature Reserve for the permit to set up the experiment.

\section{ORCID}

Christel Vidaller (iD https://orcid.org/0000-0001-5354-1677

\section{REFERENCES}

Anderson, M. J. (2001). Permutation tests for univariate or multivariate analysis of variance and regression. Canadian Journal of Fisheries and Aquatic Sciences, 58, 626-639. https://doi.org/10.1139/f01-004

Biondini, M. E., Steuter, A. A., \& Grygiel, C. E. (1989). Seasonal fire effects on the diversity patterns, spatial distribution and community structure of forbs in the Northern Mixed Prairie, USA. Vegetatio, 85, 21-31. https://doi.org/10.1007/bf00042252

Bond, W. J., \& Keeley, J. E. (2005). Fire as a global 'herbivore': the ecology and evolution of flammable ecosystems. Trends in Ecology \& Evolution, 20, 387-394. https://doi.org/10.1016/j.tree.2005.04.025

Bond, W. J., \& Parr, C. L. (2010). Beyond the forest edge: Ecology, diversity and conservation of the grassy biomes. Biological Conservation, 143, 2395-2404. https://doi.org/10.1016/j.biocon.2009.12.012

Bond, W. J. \& van Wilgen, B. W. (1996). Fire and plants. Population and Community Biology Series 14. London, UK: Chapman \& Hall.

Bond, W. J., Woodward, F. I., \& Midgley, G. F. (2005). The global distribution of ecosystems in a world without fire. New Phytologist, 165, 525-538. https://doi.org/10.1111/j.1469-8137.2004.01252.x

Borcard, D., Gillet, F., \& Legendre, P. (2011). Unconstrained ordination. In Numerical ecology with R (pp. 115-151). New York: Springer. https:// doi.org/10.1007/978-1-4419-7976-6

Borcard, D., Gillet, F., \& Legendre, P. (2011). Unconstrained Ordination. In Borcard, D., Gillet, F., \& Legendre, P. (Eds.), Numerical Ecology with $R$ (pp. 115-151). New York, NY: Springer. 
Briske, D. D., \& Noy-Meir, I. (1998). Plant responses to grazing: a comparative evaluation of annual and perennial grasses. In V. P. Papanastasis \& D. Peter (Eds.), Proceedings of the International Workshop on Ecological Basis of Live-stock Grazing in Mediterranean Ecosystems (pp. 13-26). Thessaloniki, Greece: EU report 18308.

Buhk, C., Meyn, A., \& Jentsch, A. (2007). The challenge of plant regeneration after fire in the Mediterranean Basin: scientific gaps in our knowledge on plant strategies and evolution of traits. Plant Ecology, 192, 1-19. https://doi.org/10.1007/s11258-006-9224-2

Buis, G. M., Blair, J. M., Burkepile, D. E., Burns, C. E., Chamberlain, A. J., Chapman, P. L., ... Knapp, A. K. (2009). Controls of aboveground net primary production in Mesic savanna grasslands: an interhemispheric comparison. Ecosystems, 12, 982-995. https://doi. org/10.1007/s10021-009-9273-1

Buisson, E., \& Dutoit, T. (2006). Creation of the natural reserve of La Crau: Implications for the creation and management of protected areas. Journal of Environmental Management, 80, 318-326. https:// doi.org/10.1016/j.jenvman.2005.09.013

Cassagne, N., Pimont, F., Dupuy, J.-L., Linn, R. R., Mårell, A., Oliveri, C., \& Rigolot, E. (2011). Using a fire propagation model to assess the efficiency of prescribed burning in reducing the fire hazard. Ecological Modelling, 222, 1502-1514. https://doi.org/10.1016/j. ecolmodel.2011.02.004

Caturla, R. N., Raventós, J., Guàrdia, R., \& Vallejo, V. R. (2000). Early postfire regeneration dynamics of Brachypodium retusum Pers. (Beauv.) in old fields of the Valencia region (eastern Spain). Acta Oecologica, 21, 1-12. https://doi.org/10.1016/s1146-609x(00)00114-4

Chalvet, M. (2016). La vulnérabilité de la forêt provençale face aux incendies: naissance d'une notion (fin XIXe siècle). VertigO, 16. https://doi. org/10.4000/vertigo.18012

Cingolani, A. M., Noy-Meir, I., \& Díaz, S. (2005). Grazing effects on rangeland diversity: a synthesis of contemporary models. Ecological Applications, 15, 757-773. https://doi.org/10.1890/03-5272

Clarke, P. J., Lawes, M. J., Midgley, J. J., Lamont, B. B., Ojeda, F., Burrows, G. E., ... Knox, K. J. E. (2013). Resprouting as a key functional trait: how buds, protection and resources drive persistence after fire. New Phytologist, 197, 19-35. https://doi.org/10.1111/nph.12001

Coates, F., Lunt, I. D., \& Tremblay, R. L. (2006). Effects of disturbance on population dynamics of the threatened orchid Prasophyllum correctum D.L. Jones and implications for grassland management in southeastern Australia. Biological Conservation, 129, 59-69. https://doi. org/10.1016/j.biocon.2005.06.037

Coiffait-Gombault, C., Buisson, E., \& Dutoit, T. (2012). Are old Mediterranean grasslands resilient to human disturbances? Acta Oecologica, 43, 86-94. https://doi.org/10.1016/j.actao.2012.04.011

Damgaard, C. (2014). Estimating mean plant cover from different types of cover data: A coherent statistical framework. Ecosphere, 5, 20. https://doi.org/10.1890/es13-00300.1

De Luis, M. D., Raventós, J., Cortina, J., González-Hidalgo, J. C., \& Sánchez, J. R. (2004). Fire and torrential rainfall: effects on the perennial grass Brachypodium retusum. Plant Ecology, 173, 225-232. https://doi.org/10.1023/b:vege.0000029321.92655.a6

Díaz, S., Noy-Meir, I., \& Cabido, M. (2001). Can grazing response of herbaceous plants be predicted from simple vegetative traits? Journal of Applied Ecology, 38, 497-508. https://doi. org/10.1046/j.1365-2664.2001.00635.x

Drobnik, J., Römermann, C., Bernhardt-Römermann, M., \& Poschlod, P. (2011). Adaptation of plant functional group composition to management changes in calcareous grassland. Agriculture, Ecosystems \& Environment, 145, 29-37. https://doi.org/10.1016/j. agee.2010.12.021

European Commission (2007). Interpretation Manual of European Union Habitats EUR 27. Brussels, Belgium: European Commission.

Everson, C. S., \& Everson, T. M. (1987). Factors affecting the timing of grassland regrowth after fire in the montane grasslands of Natal.
South African Forestry Journal, 142, 47-52. https://doi.org/10.1080/ 00382167.1987 .9630283

Fidelis, A., Appezzato-da-Glória, B., Pillar, V. D., \& Pfadenhauer, J. (2014). Does disturbance affect bud bank size and belowground structures diversity in Brazilian subtropical grasslands? Flora - Morphology, Distribution, Functional Ecology of Plants, 209, 110-116. https://doi. org/10.1016/j.flora.2013.12.003

Fidelis, A., \& Blanco, C. (2014). Does fire induce flowering in Brazilian subtropical grasslands? Applied Vegetation Science, 17, 690-699. https://doi.org/10.1111/avsc.12098

Fidelis, A., Blanco, C. C., Müller, S. C., Pillar, V. D., \& Pfadenhauer, J. (2012). Short-term changes caused by fire and mowing in Brazilian Campos grasslands with different long-term fire histories. Journal of Vegetation Science, 23, 552-562. https://doi. org/10.1111/j.1654-1103.2011.01364.x

Gazol, A., Tamme, R., Takkis, K., Kasari, L., Saar, L., Helm, A., \& Pärtel, M. (2012). Landscape- and small-scale determinants of grassland species diversity: direct and indirect influences. Ecography, 35, 944-951. https://doi.org/10.1111/j.1600-0587.2012.07627.x

González-Rabanal, F., Casal, M., \& Trabaud, L. (1994). Effects of high temperatures, ash and seed position in the inflorescence on the germination of three Spanish grasses. Journal of Vegetation Science, 5 , 289-294. https://doi.org/10.2307/3235851

Henry, F., Talon, B., \& Dutoit, T. (2010). The age and history of the French Mediterranean steppe revisited by soil wood charcoal analysis. The Holocene, 20, 25-34. https://doi.org/10.1177/0959683609348841

Hobbs, N. T., Schimel, D. S., Owensby, C. E., \& Ojima, D. S. (1991). Fire and grazing in the tallgrass prairie: contingent effects on nitrogen budgets. Ecology, 72, 1374-1382. https://doi.org/10.2307/1941109

Howe, H. F. (1994). Response of early- and late-flowering plants to fire season in experimental prairies. Ecological Applications, 4, 121-133. https://doi.org/10.2307/1942122

Keeley, J. E. (1993). Smoke-induced flowering in the fire-lily Cyrtanthus ventricosus. South African Journal of Botany, 59, 638. https://doi. org/10.1016/s0254-6299(16)30681-0

Keeley, J. E., Bond, W. J., Bradstock, R. A., Pausas, J. G., \& Rundel, P. W. (2012). Fire in Mediterranean ecosystems: Ecology, Evolution and Management. Cambridge, UK: Cambridge University Press.

Lamont, B. B. \& Downes, K. S. (2011). Fire-stimulated flowering among resprouters and geophytes in Australia and South Africa. Plant Ecology, 212, 2111-2125. https://doi.org/10.1007/s11258-011-9987-y

Lamont, B. B., \& He, T. (2017). Fire-proneness as a prerequisite for the evolution of fire-adapted traits. Trends in Plant Science, 22, 278-288. https://doi.org/10.1016/j.tplants.2016.11.004

Lamont, B. B., \& Runciman, H. V. (1993). Fire may stimulate flowering, branching, seed production and seedling establishment in two kangaroo paws (Haemodoraceae). Journal of Applied Ecology, 30, 256264. https://doi.org/10.2307/2404627

Landsberg, J., Lavorel, S., \& Stol, J. (1999). Grazing response groups among understorey plants in arid rangelands. Journal of Vegetation Science, 10, 683-696. https://doi.org/10.2307/3237083

Laurance, W. F. (2003). Slow burn: the insidious effects of surface fires on tropical forests. Trends in Ecology \& Evolution, 18, 209-212. https://doi.org/10.1016/s0169-5347(03)00064-8

Le Stradic, S., Silveira, F. A. O., Buisson, E., Cazelles, K., Carvalho, V., \& Fernandes, G. W. (2015). Diversity of germination strategies and seed dormancy in herbaceous species of campo rupestre grasslands. Austral Ecology, 40, 537-546. https://doi.org/10.1111/aec.12221

Leach, M. K., \& Givnish, T. J. (1996). Ecological determinants of species loss in remnant prairies. Science, 273, 1555-1558. https://doi. org/10.1126/science.273.5281.1555

Naveh,Z.(1975). The evolutionary significance of fire in the Mediterranean region. Vegetatio, 29, 199-208. https://doi.org/10.1007/bf02390011

Neary, D. G., Klopatek, C. C., DeBano, L. F., \& Ffolliott, P. F. (1999). Fire effects on belowground sustainability: a review and synthesis. Forest 
Ecology and Management, 122, 51-71. https://doi.org/10.1016/ s0378-1127(99)00032-8

Noy-Meir, I. (1995). Interactive effects of fire and grazing on structure and diversity of Mediterranean grasslands. Journal of Vegetation Science, 6, 701-710. https://doi.org/10.2307/3236441

Parr, C. L., \& Andersen, A. N. (2006). Patch mosaic burning for biodiversity conservation: a critique of the pyrodiversity paradigm. Conservation Biology, 20, 1610-1619. https://doi. org/10.1111/j.1523-1739.2006.00492.x

Peco, B., Carmona, C. P., de Pablos, I., \& Azcárate, F. M. (2012). Effects of grazing abandonment on functional and taxonomic diversity of Mediterranean grasslands. Agriculture, Ecosystems \& Environment, 152, 27-32. https://doi.org/10.1016/j.agee.2012.02.009

Pielou, E. C. (1969). An introduction to mathematical ecology. New York, NY: Wiley Interscience.

Poschlod, P., \& WallisDeVries, M. F. (2002). The historical and socioeconomic perspective of calcareous grasslands-lessons from the distant and recent past. Biological Conservation, 104, 361-376. https:// doi.org/10.1016/s0006-3207(01)00201-4

Prométhée fire database. (2018). Forest fires database for Mediterranean area in France: 1973-2018. http://www.promethee.com/

Pyke, G. H. (2017). Fire-stimulated flowering: a review and look to the future. Critical Reviews in Plant Sciences, 36, 179-189. https://doi.org/ 10.1080/07352689.2017.1364209

Pywell, R. F., Bullock, J. M., Tallowin, J. B., Walker, K. J., Warman, E. A., \& Masters, G. (2007). Enhancing diversity of species-poor grasslands: an experimental assessment of multiple constraints. Journal of Applied Ecology,44,81-94.https://doi.org/10.1111/j.1365-2664.2006.01260.x

R Development Core Team (2013). R: A language and environment for statistical computing. Vienna, Austria: R Foundation for Statistical Computing.

Saatkamp, A., Henry, F., \& Dutoit, T. (2018). Vegetation and soil seed bank in a 23-year grazing exclusion chronosequence in a Mediterranean dry grassland. Plant Biosystems, 152, 1020-1030. https://doi.org/10. 1080/11263504.2017.1407375

San Miguel, A. (2008). Management of Natura 2000 habitats. 6220 *Pseudo-steppe with grasses and annuals of the Thero-Brachypodietea. Brussels: European Commission.

Sparks, J. C., Masters, R. E., Engle, D. M., Palmer, M. W., \& Bukenhofer, G. A. (1998). Effects of late growing-season and late dormant-season prescribed fire on herbaceous vegetation in restored pine-grassland communities. Journal of Vegetation Science, 9, 133-142. https://doi. org/10.2307/3237231

Stouff, L. (1986). Arles à la fin du Moyen-Age (Vol. 1). Ph.D. thesis. Aix-enProvence, France: Provence and Lille Universities.

Symstad, A. J., Wienk, C. L., \& Thorstenson, A. D. (2008). Precision, repeatability, and efficiency of two canopy-cover estimate methods in northern Great Plains vegetation. Rangeland Ecology \& Management, 61, 419-429. https://doi.org/10.2111/08-010.1

Trabaud, L. (1979). Etude du comportement du feu dans la Garrigue de Chêne kermès à partir des températures et des vitesses de propagation. Annales des Sciences Forestières, 36, 13-38. https://doi. org/10.1051/forest/19790102
Tyler, C., \& Borchert, M. (2003). Reproduction and growth of the chaparral geophyte, Zigadenus fremontii (Liliaceae), in relation to fire. Plant Ecology, 165, 11-20. https://doi.org/10.1023/ a:1021460025277

Valone, T. J., \& Kelt, D. A. (1999). Fire and grazing in a shrub-invaded arid grassland community: independent or interactive ecological effects? Journal of Arid Environments, 42, 15-28. https://doi.org/10.1006/ jare.1999.0500

Vidaller, C., Dutoit, T., Ibrahim, Y., Hanslin, H. M., \& Bischoff, A. (2018). Adaptive differentiation among populations of the Mediterranean dry grassland species Brachypodium retusum: The role of soil conditions, grazing, and humidity. American Journal of Botany, 105, 11231132. https://doi.org/10.1002/ajb2.1116

Vilà-Cabrera, A., Saura-Mas, S., \& Lloret, F. (2008). Effects of fire frequency on species composition in a Mediterranean shrubland. Ecoscience, 15, 519-528. https://doi.org/10.2980/15-4-3164

\section{SUPPORTING INFORMATION}

Additional supporting information may be found online in the Supporting Information section at the end of the article.

Appendix S1 Climate diagram of Saint-Martin de Crau.

Appendix S2 Full list of the 138 species found in the study zone.

Appendix S3 Design of the combined fire and grazing experiment and the fire experiment in long-term exclosures.

Appendix S4 Thermal weeder device.

Appendix S5 Effects of fire and grazing treatments on plant species most benefitting from fire in the combined fire and grazing experiment $(A)$ and the fire experiment in long-term exclosures (B) one year after fire treatments (May 2017).

Appendix S6 Results of Permutational Multivariate Analysis of Variance (PERMANOVA) contrast pairwise tests between different levels of fire treatment.

Appendix S7 Effects of fire and grazing treatments on plant species most benefitting from fire in the combined fire and grazing experiment and the fire experiment in long-term exclosures. 